\title{
The Extent and Forms of Voluntary Disclosure of Financial Information on Internet in Nigeria: An Exploratory Study
}

\author{
Mary Kehinde Salawu \\ Department of Management and Accounting, Obafemi Awolowo University, Ile-Ife, Nigeria \\ E-mail: marysalawu@yahoo.com, rsalawu@oauife.edu.ng
}

Received: October 21, 2012

Accepted: November 14, 2012

Online Published: December 23, 2012

doi:10.5430/ijfr.v4n1p110

URL: http://dx.doi.org/10.5430/ijfr.v4n1p110

\begin{abstract}
This study determined the extent and form of internet financial reporting by quoted companies in Nigeria. The study employed secondary data. One hundred and fifty-five financial and non-financial firms quoted on the Nigerian Stock Exchange (NSE) were purposively selected for analysis. These comprise 49 financial firms and 106 non-financial firms between 2009 and 2010. Data relating to financial reporting on the internet were obtained from the websites of the sampled companies. Content and descriptive analyses were employed to analyse data. Findings revealed that 139 companies which constitute $90 \%$ of the listed companies have websites while $16(10 \%)$ have no website. Ninety-eight percent of the financial sector comprising of Banking, Insurance, Mortgage and other Financial Institutions have websites. Out of the total of the 139 companies with website, only 77 (55\%) disclosed financial information on their web pages while the remaining $62(45 \%)$ did not. The study recommends that Government and stock market regulators should put in place regulatory framework for internet financial reporting and companies should release both the online report and hard copy promptly.
\end{abstract}

Keywords: Reporting, Internet, Disclosure, Financial, Nigeria

\section{Introduction}

Financial Reporting is regarded as an important and effectual means of disseminating financial information. Company and Allied Matter Act requires the Directors of every company especially a public limited liability company to lay before the company in general meeting, certain financial statements at least once in every calendar year. The financial statements are usually printed and compiled in an Annual Reports and Accounts of such Companies. Some of these companies may in addition, be required to also publish them in the news papers. According to Atrill and Mclaney (1997), the major financial statements are designed to provide a picture of the overall financial position and performance of the business. In order to provide this, the accounting system will normally produce three major components in the financial reports on a regular recurring basis. These three major components are concerned with answering the following questions: What cash movements (i.e. cash in and cash out) took place over a particular period? How much wealth (i.e. profit) was generated by the business over a particular period? What is the accumulated wealth of the business at the end of a particular period?

The published Annual Reports and Accounts usually contain the following: Chairman's report, Director's report, Auditor's report, Audit Committee Report, Statement of accounting policies, Notes to the Accounts, Comprehensive Income Statement, Statement of Financial Position, Cash flow Statement, Value Added Statement and Five Years Financial Summary. Financial reports play an important role in companies, with high importance, because it reflects the efficiency and effectiveness in the management of the company and the work undertaken by the company.

In the past, all listed companies presented their financial report manually. This was done through the printed-based annual report or the paper-based annual report. The printed-based annual report entails writing and printing of financial information. It is mandatory in practice to send a copy of the annual financial report to the Nigerian Stock Exchange (NSE). Moreover, the Nigerian Stock Exchange produces a fact book annually that contains five years financial summary of all the listed companies on the stock exchange. At present, the use of the Internet has provided a new avenue for companies to communicate with current and potential investors. Almost every company maintains its website, especially in developed countries as evidenced by literature. However, the content, extent and format of disclosure on the website are yet to be standardized and different companies are adopting different practices in this regards. Internet financial reporting appears to be a viable alternative to paper-based form of reporting but the extent 
and forms of disclosure by the quoted companies in Nigeria are yet to be ascertained. These are the issues this paper is set to address. The rest of the paper is organized as follows: Section 2 briefly examines the literature review; Section 3 presents method of analysis; Section 4 centers on the discussion of the results; while Section 5 is devoted to conclusion and recommendations.

\section{Literature Review}

In early studies, researchers used descriptive analysis only to offer a general overview of the current state of internet financial reporting and disclosure in different countries. Since 1995, interest in the Internet has grown due to the availability of the World Wide Web. Professional and academic studies started to be published shortly thereafter. Rapid developments in information and communication technology have led scholars and people in many countries to consider the impact of web-based financial reporting and several other issues relating to the topic. Many of these studies focused on the existence of web pages for large listed companies and whether these companies disclosed some type of financial information on their web pages.

Lymer and Tallberg, (1997) study included 50 top UK companies and 72 Finnish listed companies. Allam and Lymer (2003) compared internet financial reporting among 250 companies across five countries (USA, UK, Canada, Australia and Hong Kong). They discovered that US companies had higher levels of internet financial disclosure and

Hong Kong had the lowest level of internet financial disclosure. Debreceny and Gray (1999) compared internet financial disclosure of the 15 largest companies in each of UK, Germany and France. Khadaroo (2005) compared internet financial reporting among 100 Malaysian and 45 Singaporean companies and discovered that Singaporean companies use more internet financial reporting than their Malaysian counterparts.

Ashbaugh, Johnstone and Warfield (1999) examine a sample of 290 US companies. They reported that 87\% (252) of the companies had a website and 70\% (176) of these disseminated financial reporting. Gowthorpe and Amat (1999) examine 379 Spanish companies and reported that only $19 \%$ have websites, and that $55.7 \%$ of these companies provide financial information on their home page. Ettredge et al. (2001) focus on the nature of financial information of 490 US firms and show that larger and high-tech companies are likely to provide more information than other firms. The studies fail to identify the factors influencing internet financial reporting. Also, Craven and Marston (1999) investigate 206 large firms in 1998. They reported that 74\% (153) of these firms had website and 71\% (109) had financial reporting on their websites. It was discovered by them that larger firms were more likely to disclose more information on their websites. Industry as a variable was not significant in their study.

Deller et al. (1999) analyze investor related information included on websites of US, UK and German in 1998. They show that respectively $91 \%, 72 \%$ and $71 \%$ of US, UK AND German firms use Internet financial reporting. The study was purely descriptive and fails to examine the determinants of IFR. Also, Ettredge, Richardson and Schoiz (2002) analyzed a sample of 220 US companies in 1997. They reported that $87 \%$ (193) had websites, while only disseminated financial reporting via their websites. However, the study only examines the content aspect of disclosure.

Geerings et al. (2003) examine the top 50 companies from Belgium, France and Netherlands. They report more developed Internet practices in France and Netherlands than in Belgium. A comparative research on 5 countries covering Australia, Canada, Hong Kong, UK and USA, was carried out by Allam and Lymer (2003). They show that $96 \%$ of the studied firms publish a number of financial items including balance sheets, profit and loss accounts and cash flow reports. The findings of these studies shed light on significant differences in Internet practices across countries. However, they provide little theoretical background for their analysis and do not consider practice differences within one country.

Prabowo and Tambotoh (2005) examine internet financial reporting as a voluntary disclosure practice by Indonesian Manufacturing firms. Their results reported that most Indonesian manufacturing firms have their own websites. But the utilization of their websites for financial reporting is still low. According to them IFR is voluntary not because of the content of information, but because securities market regulator does not stipulate companies to inform their financial statements in their website, even the possession of website is neither stipulated. Ragab and Omran (2006) examine the extent to which national and international investors in the Egyptian Stock market perceive accounting information to be useful for valuing stocks. They found that accounting information is value relevant information in the Egyptian stock market and argued that the market needs complementary information sources other than published accounting reports to become more efficient.

Al-Shammari (2007) examined a sample of 143 companies listed on the Kuwait Stock Exchange on the use of the Internet for disseminating financial reporting information. The results reported 77\% (110) had websites and 70\% (77) 
disseminated financial reporting information on their websites. Donmez et al. (2007) examined the extent and determinants of voluntary financial disclosures on the internet by publicly traded Turkish companies. They found that $72 \%$ of the companies have formal web pages while only half of those provide voluntary financial disclosures on the internet. They discovered that companies adopting voluntary financial disclosures on the internet have higher total assets, higher market value, higher profitability and lower financial leverage.

Aly and Simon (2008) investigate 98 Egyptian listed companies through content analysis. The results show that out of 98 companies surveyed only 68 had websites. The results for the sample of 68 companies show that over $50 \%$ companies voluntary report financial information on their websites. Salawu (2009) examines the status of financial reporting on the internet by the Nigerian listed companies. The study shows that, 119 (54.1\%) companies have official website while 101 (45.9\%) do not have an official website. Furthermore, 31 (14.1\%) companies publish their financial information on-line while $189(85.9 \%)$ do not publish their financial information on-line. Turel (2010) examined the expectation gap in internet financial reporting in Turkey. It was discovered that, the entire sample companies (98) included in their study had web pages and 94 (95\%) of these companies disclosed financial information on their web pages. The results also indicated that an expectation gap exist; financial statement users have higher expectations for various facets than what companies actually report in the areas such as reports of analysis, phone number to investors relations, segmental reporting etc.

The issue of financial information disclosure by Nigerian quoted companies has been unsatisfactory despite the introduction of several financial reporting standards over the years. The use of paper-based annual reports as a means of communicating financial information to shareholders limits the content of needed qualitative information disclosed, thus, increasing the risks of companies being undervalued by market. The objective of this paper therefore is to determine the extent and forms of internet financial reporting by quoted companies in Nigeria using content analysis.

\section{Research Method}

The samples for the study were drawn from both financial and non-financial companies listed on the Nigerian Stock Exchange on the grounds that they are more likely to have a websites and provide Internet financial information. The 2010 Fact Book published by the Nigeria Stock Exchange revealed that, 155 companies are listed on the stock exchange. The sample covers 155 firms which comprise 49 financial and 106 non-financial firms listed on the Nigerian Stock Exchange (NSE). The companies' annual report and accounts are consulted to obtain web addresses for the relevant companies. The websites of the sampled companies were browsed for collecting data relating to financial reporting on the internet. The www.google.com was the major search engine used in addition to the government site www.sec.gov.ng and www.nigerianstockexchange.com/quoted-company. Descriptive statistics such as table, percentage and content analysis were used.

\section{Discussion and Results}

Content analysis was carried out in order to examine the extent and form of internet financial reporting by one hundred and fifty-five (155) quoted companies in Nigeria as at 2010. These cover firms with Websites and Non-Websites, Analysis of Financial Information Disclosure, Analysis of Non-Financial Information Disclosure, Financial Information Disclosure formats and Investors' Relation Information.

\subsection{Firms with Websites and Non-Websites}

Table 1 presents the distribution of websites and non-website companies listed on the market of Nigerian Stock Exchange (NSE) by industry. One hundred and thirty-nine (139) companies have websites, which constitute about (90\%) of the listed companies while sixteen (16) companies have no website, these also account for about $10 \%$ of the total 155 companies as listed on the NSE.

Agriculture and Agro-Allied, Airline Services, Banking, Commercial/Services, Computer and Office Equipment, Conglomerates, Construction, Engineering Technology, Healthcare, Information and Communication Technology, Leasing, Maritime, Media, Mortgage companies and other Financial Institutions sectors have the highest proportion of corporate websites of (100\%) each; compared to Second-Tier Securities with only (33\%), Real Estate Investment Trust and Textiles Industries with (0\%) website. Also, about (67\%) of the Second-Tier Securities have no official websites as well as some companies in Automobile and Tyre (50\%), Hotel and Tourism (50\%), Breweries (40\%)Building and Materials (40\%), and few others with (25\%) and below.

This study shows an improvement in the number of corporate website existence especially in Engineering Technology (100\%) and Other Financial Institutions (100\%) which according to Salawu (2009) had (0\%) each in term of website. Other industries which had also expanded in number of internet activities since the 2009 study 
include Agriculture and Agro-Allied, Airline Services, Aviation, Food, Beverages and Tobacco, Mortgage and Telecommunication.

However, there is a sharp reduction in the number of companies that have official website among the Second-Tier Securities as reported by Salawu (2009) to be four (4) but now one (1), that is, Capital Oil Plc. It is important to note that during the course of the study, it was found out that the official websites of some companies were still undergoing development or contained no vital information of either investor-related or financial in nature.

$<$ Insert Table 1 Here>

It could be seen from Table 2 that (98\%) of the Financial Sector comprising of Banking, Insurance, Mortgage and Other Financial Institutions have websites. It could be said that companies in the Financial sector might have recognized the benefits of internet technology faster and more than the companies in the Non-Financial sector. This might be due to the fact that after the consolidation of the Banks especially, the web page is used to emphasise their marketing strategies, enhance their corporate image and to have competitive advantage. This result is consistent with (Lymer et al., 1999; Ashbauph et al., 1999 and Davey and Homkajohn, 2004). Also, virtually all the companies in the Insurance group engage in Internet financial reporting practices; this is in line with the findings of Xiao et al., (2004) who found that industrial difference has an influence on Internet financial reporting in china.

$<$ Insert Table 2 Here $>$

\subsection{Analysis of Financial Information Disclosure}

Out of the total of one hundred and thirty-nine (139) companies with websites, only seventy-seven (77), that is, about $(55 \%)$ disclosed financial information on their web pages while the remaining sixty-two, that is, about (45\%) did not disclose financial information on their websites. The seventy-seven companies represent only nineteen (19) industries out of the total of thirty (30) industries with web presence as analysed in Table 3. It was found out in the course of this study that companies that did not disclose financial information on their websites used the websites mainly for promoting and marketing their products or services, answering customers' inquiries, presenting new events, providing background information about the company, enhancing corporate image through much philanthropic activities disclosed and encouraging investment in the shares of their companies.

Apart from Building Materials, Commercial/Services, Leasing, Road Transportation and Printing and Publishing industries that recorded $100 \%$ disclosure on industry basis, Banking (13) and Insurance companies (15) of the financial sector had the highest number of companies that disclosed their companies' financial information on-line as against the non-financial companies. Distinct factors that could be responsible for these include the nature of business operation of banks and other related companies such as intensive international operations and loans, letters of credit, foreign exchange contracts and currency swap, strong competition, intensive use of advanced technology to enhance advance services in form of visa cards, electronic fund transfer, payment of bills, issuance of drafts and handling of inquires on the internet. This result is consistent with the findings of Salawu (2009).

Signalling theory suggests industry difference in disclosure. If a company within industry failed to follow disclosure practices, including internet disclosure of others in the same industry then it may be interpreted that the company is hiding bad news. Going by this theory, it may be that the three (3) companies in Agro-Allied -one (1) in airline Services, eight (8) in Banking, one (1) in Breweries, two (2) in Chemical and Paints, one (1) in Computer and Office Equipment, three (3) in Conglomerates, one (1) in Construction, four (4) in Food / Beverages and Tobacco, three (3) in Healthcare, eleven (11) in Insurance, two (2) in Mortgage, one (1) in Other Financial Institution and one (1) in Petroleum(Marketing) are all have one bad news or the other they would not want the public to be aware of that prevents them from disclosing the information expected on the web page. Generally, the study reveals that the nature of IFR disclosure varies considerably across the sample firms. The variations in the content of the websites' suggest that firms had different reasons for establishing an Internet presence. Some websites contain only product and service advertising. This finding is consistent with that of Budisusetyo and Almilia (2008).

$<$ Insert Table 3 Here>

\section{Past Years Financial Information Disclosure}

In Table 4, the items of financial information mostly reported by companies on their official websites include the Balance Sheet, Income Statement, Cash-flow Statement, Notes to the Account, Five Years Financial Summary, Statement of Significant Accounting Policies, Value Added Statement and Auditor's Report of the past years. The analysis on Table 4.4 shows the following percentages of the previous years' financial statements disclosed despite the fact that the statement of the latest year under study should have been provided another year-Balance Sheet 
(83\%), Income Statement (83\%), Cash Flow Statement (70\%), Notes to the financial Statement (73\%), Five-year Financial Summary (73\%), Statement of Significant Accounting Policies (71\%).

The pattern of the various items disclosed is consistent with the pattern of disclosure but lower in percentage as found by Al-Sakarneh (2011) in his study on similar subject on companies quoted on Amman Stock Exchange Jordan. This indicates that some of the quoted companies on the NSE are still lagging behind in making up their annual financial statement. This deficiency needs to be urgently addressed by the management since the investors cannot take any reasonable economic decision regarding their investment in such companies. In the same vein, such companies would most often face higher cost of capital if at all they could attract any. Worse still, such companies would find it difficult to favourably attract investors in the face of competitive economy. Moreover, the problem of non-transparency would persist as the other economic agents would not be able to accurately capture their expected return from such organisation, for example, the Inland Tax Revenue.

It is worthy of note that most of the companies do not make appropriate full benefits of internet disclosure to add value to the financial information disclosed, rather, the outlook of the financial information is more or less a mere duplication of the paper version leaving both the text and the graphics static.

\section{Current Year Financial Information Disclosure}

The current year quarterly, Half-yearly and Interim reports of companies provide more up to date and timely information to users as they might not gain access the full report of the year until about three months after the year end. As presented in Table 4, only about (38.96\%), (19.48\%) and (24.67\%) of the seventy-seven (77) companies reported their current quarterly, half-yearly and full excerpt report respectively on-line. Other current report items include the Balance Sheet of the current year, (24.67\%), Income Statement of the Current year (22.08\%), Cash-flow Statement of the Current year (23.38\%), Notes to the Account of the Current year (18.18\%) as well as the Auditor' Report of the Current year. The low percentage of the current year financial disclosure is a reflection of the spill over effect of the backlog of previous years' financial statements. At this point, it could be affirmed that the Companies in Nigeria are less ready to meet up with the international standard of reporting as at when due. Once companies have decided to furnish the public with the financial information of their corporation, statement of financial position and of the performance are no longer confidential, then such disclosure should meet up with the minimum level of requirement acceptable to the direct and the indirect beneficiaries. That is, it should be timely, accurate, clear, complete and relevant to the decision making of the users.

\section{Complete Set of Annual Report}

A complete set of annual financial reports provide more financial information for decision making than do the simplified quarterly, semi-annual or excerpt annual report. The study of the companies that disclosed financial information on their websites shows that forty-two (42) have complete set of past financial statements and only twelve (12) have the complete set of the present year statement on line making about (55\%) and (16\%) respectively out seventy-seven (77) companies as analyzed in Table 4.4.

\section{Interim Report Disclosure}

It is observed from Table 4 that about 19\% of the entire companies present their interim financial report while about $30 \%$ present an abridged form of financial statement when in actual fact they are required to disclosed their full financial information. The reason behind this may be to sidetrack the auditor's report which is mandatory in the case of a complete set. In the absence of Auditor's Report, whatever report is presented has no basis for reliability.

$<$ Insert Table 4 Here $>$

\section{Conclusion}

It was found out in the course of this study that there is under-utilization of Internet Financial Reporting. This could have resulted from absence of any regulatory framework or for lack of knowledge of the implications of reporting in an electronic environment. The findings show that the nature of IFR disclosures varies considerably across the sample companies. The variation in the content of the websites may be due to the fact that there is no regulation as yet to specify what exactly of how the presentation should be. It further suggests that individual company has different motivating factors for establishing an Internet presence. Some companies' websites contain only product and service advertising with a bit of customer commitment charter.

With respect to the amount of accounting data provided, only very few of Nigerian quoted companies' websites present a full set of financial statements, many present only the interim report while a host of others do not present any meaningful financial report. Due to the dynamic business world and introduction of International Financial 
Reporting Standard (IFRS) in Nigeria, traditional paper based corporate reporting is becoming increasingly less timely and thus less useful to decision makers. Shifting the focus of accounting from an aggregation concept premised on periodic reports to one premised on real-time access to disaggregated data permits access to more timely information (Wallman, 1997). Based on the findings of this study, the following recommendations are suggested: (i) Government and stock market regulators should put in place regulatory framework for internet financial reporting. (ii) Companies should release both the online report and hard copy promptly, (iii) Companies should provide audit reports in relation to all their published financial statement and at the same time clearly demarcate the audited report from unaudited report released online.

\section{References}

Allam, A., \& Lymer, A. (2003). Developments in Internet financial reporting: Review and analysis across five developed countries. The International Journal of Digital Accounting Research, 3(6), 165-206.

Al Sakarneh K.H.I. (2011). A study on the Internet Financial Reporting Disclosure: A case of companies listed at Amman Stock Exchange, Jordan. A Thesis submitted to the UUM Graduate School of Business, Universiti Utara Malaysia.

Al-Shammari, T.B. (2007). Determinants of Internet Financial Reporting by Listed Companies on the Kuwait Exchange. Journal of International Business and Economics, VII(1), 162-179.

Aly, A., \& Simon, J. (2008). Assessing the development of voluntary internet financial reporting and disclosure in Egypt. Paper presented at the British Accounting Association Conference, Blackpool, UK.

Ashbaugh, H., Johnstone, K. M., \& T. D. Warfield. (1999). Corporate Reporting on the Internet. Accounting Horizons, 13(3), 241-257. http://dx.doi.org/10.2308/acch.1999.13.3.241

Atril, P., \& Mclaney, E. (1997). Accounting and Finance for Non-Specialists. Pretice Hall, London.

Budisusetyo, S., \& Almilia, L. S. (2008). The Practice of Financial Disclosure on Corporate Website: Case Study in Indonesia. Proceeding International Conference on Business \& Management. Universiti Brunei Darussalam, 8 - 9 January.

Craven, B. M., \& Marston, C. L. (1999). Financial reporting on the Internet by leading UK companies. The European Accounting Review, 8(2), 321-333. http://dx.doi.org/10.1080/096381899336069

Davey, H., \& Homkajohn, K. (2004). Corporate Internet Reporting: An Asian Example. Problems and Perspectives in Management, (2), 211-227

Debreceny, R., \& Gray, G. L. (1999). Financial reporting on the Internet and the external audit. European Accounting Review, 8(2), 335-350. http://dx.doi.org/10.1080/096381899336078

Deller, D., Stubenrath, M., \& Weber, C. (1999). A survey on the use of the Internet for investor relations in the USA, the UK and Germany. European Accounting Review, 8(2), 351-364. http://dx.doi.org/10.1080/096381899336087

Donmez, A., Berberoglu, P. B., Utku, B. D., \& Bozcuk, A. (2007). Internette Finansal Raporlama: IMKB de Islem Goren Sirketler Uzerine Bir Inceleme. Marmara Universitesi Muhasebe-Finansman Arastirma ve Uygulama Dergisi, Cilt:8 Yil:16 Sayi:17, pp.103-114.

Ettredge, M., Richardson, V. J., \& Scolz, S. (2001). The Presentation of Financial Information at Corporate Websites. International Journal of Accounting System, 1(2), 149-168. http://dx.doi.org/10.1016/S1467-0895(00)00017-8

Ettredge, M., Richardson, V. J., \& Scolz, S. (2002). Dissemination of information for investors at corporate web site. Journal of Accounting \& Public Policy, 21(4-5), 357-369. http://dx.doi.org/10.1016/S0278-4254(02)00066-2

Geerings, J., Bollen L., \& Hassink, H. (2003). Investor Relations on the Internet: A Survey of the Euronext Zone. European Accounting Review, 12(3), 567-579. http://dx.doi.org/10.1080/0963818032000083531

Gowthorp, C., \& Amat, O. (1999). External Reporting of Accounting and Financial Information via the Internet in Spain. European Accounting Review, 8(2), 365-371. http://dx.doi.org/10.1080/096381899336096

Khadaroo, M. I. (2005). Business reporting on the Internet in Malaysia and Singapore: A comparative study. Corporate Communications, 10(1), 58-68. http://dx.doi.org/10.1108/13563280510578204

Lymer, A., Debreceny, R., Gray, G. L., \& Rahman, A. (1999). Business reporting on the Internet. London, International Accounting Standards Committee. 
Lymer, A., \& Tallberg, A. (1997). Corporate reporting and the internet - a survey and commentary on the use of the WWW in corporate reporting in the UK and Finland. Paper presented at EAA' 97. Graz, Austria.

Prabowo, R., \& Tambotoh, J. J. C. (2005). Internet Financial Reporting as a Voluntary Disclosure Practice: An Empirical Analysis of Indonesian Manufacturing Firms Using Order Logit Regression. Jurnal Akuntansi \& Bisnis, 5(2), 149-160.

Ragad, A. A., \& Omran, M. M. (2006). Accounting information, value relevance and investors' behavior in the Egyptian equity market. Review of Accounting and Finance, 5(3), 279-297. http://dx.doi.org/10.1108/14757700610686444

Salawu, R.O. (2009). Financial Reporting on the Internet by Quoted Companies in Nigeria. Proceeding of the International Academy of African Business and Development (IAABD) $10^{\text {th }}$ Anniversary International Conference, Makerere University, Uganda, Pp. 1-7.

Turel, A. (2010). The Expectation Gap in Internet Financial Reporting: Evidence from an Emerging Capital Market. Middle Eastern Finance and Economics, (8), 94-107.

Xiao, J. Z., Yang, H., \& Chow, C. W. (2004). The determinants and characteristics of voluntary Internet-based disclosures by listed Chinese companies. Journal of Accounting \& Public Policy, 23(3), 191-225. http://dx.doi.org/10.1016/j.jaccpubpol.2004.04.002

Table 1. Distribution of website and non-website using companies by industry as classified by the Nigerian stock exchange

\begin{tabular}{|l|c|c|c|c|c|}
\hline INDUSTRY & TOTAL & \multicolumn{2}{l|}{ WEBSITE } & \multicolumn{2}{l|}{ NO WEBSITE } \\
\hline Agriculture/Agro-Allied & 4 & 4 & $100 \%$ & - & \\
\hline Airline services & 2 & 2 & $100 \%$ & - & \\
\hline Automobile \& Tyre & 2 & 1 & $50 \%$ & 1 & $50 \%$ \\
\hline Banking & 21 & 21 & $100 \%$ & - & \\
\hline Breweries & 5 & 3 & $60 \%$ & 2 & $40 \%$ \\
\hline Building Materials & 5 & 3 & $60 \%$ & 2 & $40 \%$ \\
\hline Chemical \& Paints & 7 & 6 & $85.7 \%$ & 1 & $14.3 \%$ \\
\hline Commercial/Services & 3 & 3 & $100 \%$ & - & \\
\hline Computer \& Office Equipment & 2 & 2 & $100 \%$ & - & \\
\hline Conglomerates & 8 & 8 & $100 \%$ & - & \\
\hline Construction & 3 & 3 & $100 \%$ & - & \\
\hline Engineering Technology & 2 & 2 & $100 \%$ & - & \\
\hline Food / Beverages \& Tobacco & 13 & 12 & $92.3 \%$ & 1 & $7.7 \%$ \\
\hline Healthcare & 7 & 7 & $100 \%$ & - & \\
\hline Hotel \& Tourism & 2 & 1 & $50 \%$ & 1 & $50 \%$ \\
\hline Industrial / domestic Products & & & & & \\
\hline Information \& Communication Technology & 3 & 3 & $100 \%$ & - & \\
(ITC) & & 3 & $75 \%$ & 1 & $25 \%$ \\
\hline Insurance & 27 & 26 & $96.3 \%$ & 1 & $3.7 \%$ \\
\hline Leasing & 1 & 1 & $100 \%$ & - & \\
\hline Maritime & 1 & 1 & $100 \%$ & - & \\
\hline Media & 2 & 2 & $100 \%$ & - & \\
\hline Mortgage Companies & 4 & 4 & $100 \%$ & - & \\
\hline Other Financial Institutions & 4 & 4 & $100 \%$ & - & \\
\hline Packaging & 4 & 3 & $75 \%$ & 1 & $25 \%$ \\
\hline Petroleum (Marketing) & 8 & 7 & $87.7 \%$ & 1 & $12.5 \%$ \\
\hline Printing \& Publishing & 3 & 3 & $100 \%$ & - & \\
\hline Real Estate & 1 & - & $100 \%$ & - & \\
\hline Real Estate Investment Trust & & & 1 & $100 \%$ \\
\hline
\end{tabular}




\begin{tabular}{|l|c|c|c|c|c|}
\hline Road Transportation & 1 & 1 & $100 \%$ & - & \\
\hline Textiles & 1 & - & & 1 & $100 \%$ \\
\hline The Foreign Listings & 1 & 1 & $100 \%$ & - & \\
\hline Second-Tier Securities & 3 & 1 & $33.3 \%$ & 2 & $66.7 \%$ \\
\hline GRAND TOTAL & $\mathbf{1 5 5}$ & $\mathbf{1 3 9}$ & & $\mathbf{1 6}$ & \\
\hline
\end{tabular}

Source: Field survey 2012

Table 2. Website analysis by financial and non financial sectors

\begin{tabular}{|c|c|c|c|c|c|}
\hline & TOTAL & \multicolumn{2}{|c|}{ WEBSITE } & \multicolumn{2}{c|}{ NO WEBSITE } \\
\hline SECTORS & $\begin{array}{c}\text { NUMBER OF } \\
\text { FIRMS }\end{array}$ & $\begin{array}{c}\text { NUMBER OF } \\
\text { FIRMS }\end{array}$ & $\begin{array}{c}\text { \% of Sector } \\
\text { No of } \\
\text { Firms }\end{array}$ & $\%$ \\
\hline FINANCIAL & 56 & 55 & $98 \%$ & 1 & $2 \%$ \\
\hline NON FINANCIAL & 99 & 84 & $85 \%$ & 15 & $15 \%$ \\
\hline TOTAL & $\mathbf{1 5 5}$ & $\mathbf{1 3 9}$ & $\mathbf{9 0 \%}$ & $\mathbf{1 6}$ & $\mathbf{1 0 \%}$ \\
\hline
\end{tabular}

Source: Field Survey 2012

Table 3. Analysis of financial information (FI) disclosure by industry

\begin{tabular}{|l|c|c|c|}
\hline INDUSTRY & $\begin{array}{l}\text { Total number of } \\
\text { Firms }\end{array}$ & $\begin{array}{l}\text { No of firms that } \\
\text { disclose FI }\end{array}$ & $\begin{array}{l}\% \text { in Each } \\
\text { Industry }\end{array}$ \\
\hline Agriculture/Agro-Allied & 4 & 1 & $25 \%$ \\
\hline Airline services & 2 & 1 & $50 \%$ \\
\hline Automobile \& Tyre & 1 & - & $0.0 \%$ \\
\hline Banking & 21 & 13 & $62 \%$ \\
\hline Breweries & 3 & 2 & $67 \%$ \\
\hline Building Materials & 3 & 3 & $100 \%$ \\
\hline Chemical \& Paints & 6 & 4 & $67 \%$ \\
\hline Commercial/Services & 3 & 3 & $100 \%$ \\
\hline Computer \& Office Equipment & 2 & 1 & $50 \%$ \\
\hline Conglomerates & 8 & 5 & $63 \%$ \\
\hline Construction & 3 & 2 & $67 \%$ \\
\hline Engineering Technology & 2 & - & $0.0 \%$ \\
\hline Food / Beverages \& Tobacco & 12 & 8 & $67 \%$ \\
\hline Healthcare & 7 & 3 & $43 \%$ \\
\hline Hotel \& Tourism & 1 & - & $0.0 \%$ \\
\hline Industrial / domestic Products & 3 & - & $0.0 \%$ \\
\hline Information \& Communication Technology (ITC) & 3 & - & $0.0 \%$ \\
\hline Insurance & 26 & 15 & $58 \%$ \\
\hline Leasing & 1 & 1 & $100 \%$ \\
\hline Maritime & 1 & - & $0.0 \%$ \\
\hline Media & 2 & - & $0.0 \%$ \\
\hline Mortgage Companies & 4 & 2 & $50 \%$ \\
\hline Other Financial Institutions & 4 & 3 & $75 \%$ \\
\hline Packaging & 3 & - & $0.0 \%$ \\
\hline Petroleum (Marketing) & 7 & 6 & $86 \%$ \\
\hline Printing \& Publishing & 3 & 3 & $100 \%$ \\
\hline Real Estate & 1 & - & $0.0 \%$ \\
\hline Road Transportation & 1 & 1 & $100 \%$ \\
\hline The Foreign Listings & 1 & - & $0.0 \%$ \\
\hline Second-Tier Securities & 139 & - & $0.0 \%$ \\
\hline TOTAL & & 77 & $49.7 \%$ \\
\hline Source: Fien Survey 20 & & \\
\hline
\end{tabular}

Source: Field Survey 2012 
Table 4. Summary of financial information disclosure by companies with websites

\begin{tabular}{|l|r|r|}
\hline FINANCIAL ITEMS DISCLOSED & $\begin{array}{l}\text { NO OF } \\
\text { COMPANIES }\end{array}$ & $\begin{array}{l}\text { GENERAL \% OF } \\
\text { COMPANIES }\end{array}$ \\
\hline Quarterly report of current year & 30 & $38.96 \%$ \\
\hline Quarterly report of past years & 28 & $36.36 \%$ \\
\hline Half-year report of current year (interim statements) & 15 & $19.48 \%$ \\
\hline Half-year report of past years (interim statements) & 14 & $18.18 \%$ \\
\hline Annual report of current year(full text) & 12 & $15.58 \%$ \\
\hline Annual report of past years (full test) & 42 & $54.55 \%$ \\
\hline Annual report of current year (excerpt) & 19 & $24.67 \%$ \\
\hline Annual report of past years (excerpt) & 23 & $29.87 \%$ \\
\hline Auditor report of current year & 9 & $11.69 \%$ \\
\hline Auditor's report of past years & 48 & $62.34 \%$ \\
\hline Balance sheet of current year & 19 & $24.67 \%$ \\
\hline Balance sheet of past years & 64 & $83.12 \%$ \\
\hline Income statement of current year (Profit and loss account) & 17 & $22.08 \%$ \\
\hline Income statement of past years & 64 & $83.12 \%$ \\
\hline Cash flow statement of current year & 18 & $23.38 \%$ \\
\hline Cash flow statement of past years & 54 & $70.13 \%$ \\
\hline Notes to financial statements for current year & 14 & $18.18 \%$ \\
\hline Notes to financial statements of past years & 56 & $72.96 \%$ \\
\hline Segmental reporting by line of business in current year annual & & \\
report & 31 & $40.26 \%$ \\
\hline Summary of key ratio over at least three years & 19 & $24.67 \%$ \\
\hline Five Years Financial Summary & 56 & $72.72 \%$ \\
\hline Accounting policies & 55 & $71.43 \%$ \\
\hline Information providing a dividend reinvestment plan & 42 & $54.54 \%$ \\
\hline Value Added Statement & 51 & $66.23 \%$ \\
\hline Chairman's Report & 44 & $57.14 \%$ \\
\hline
\end{tabular}

Source: Field Survey 2012 
Appendix I. Industrial percentage of quoted companies with websites

\begin{tabular}{|l|c|}
\hline \multicolumn{1}{|c|}{ LIST OF INDUSTRIES } & INDUSTRIAL \% \\
\hline Agriculture/Agro-Allied & 2.9 \\
\hline Airline services & 1.4 \\
\hline Automobile \& Tyre & 0.7 \\
\hline Banking & 15.1 \\
\hline Breweries & 2.2 \\
\hline Building Materials & 2.2 \\
\hline Chemical \& Paints & 4.3 \\
\hline Commercial/Services & 2.2 \\
\hline Computer \& Office Equipment & 1.4 \\
\hline Conglomerates & 5.8 \\
\hline Construction & 2.2 \\
\hline Engineering Technology & 1.4 \\
\hline Food / Beverages \& Tobacco & 8.6 \\
\hline Healthcare & 5.0 \\
\hline Hotel \& Tourism & 0.7 \\
\hline Industrial / domestic Products & 2.2 \\
\hline Information \& Communication Technology (ITC) & 2.2 \\
\hline Insurance & 18.7 \\
\hline Leasing & 0.7 \\
\hline Maritime & 0.7 \\
\hline Media & 1.4 \\
\hline Mortgage Companies & 2.9 \\
\hline Other Financial Institutions & 2.9 \\
\hline Packaging & 2.2 \\
\hline Petroleum (Marketing) & 5.0 \\
\hline Printing \& Publishing & 2.2 \\
\hline Real Estate & 0.7 \\
\hline Real Estate Investment Trust & 0 \\
\hline Road Transportation & 0.7 \\
\hline Textiles & 0 \\
\hline The Foreign Listings & 0.7 \\
\hline Second-Tier Securities & 0.7 \\
\hline GRAND TOTAL & $\mathbf{1 0 0}$ \\
\hline & \\
\hline
\end{tabular}

